\title{
Breeding abundance of threatened raptors as estimated from occurrence data
}

\author{
MAURIZIO SARÀ* \\ Dipartimento di Biologia Animale, Università di Palermo, Via Archirafi 18, 90123 Palermo, Italy
}

\begin{abstract}
A model derived from the negative binomial distribution (NBD) has been proposed to solve the problem of predicting abundance of species from occurrence maps. The viability of NBD was explored for predicting the breeding abundance of five threatened species of raptor: Bonelli's Eagle Hieraaetus fasciatus, Golden Eagle Aquila chrysaetos, Peregrine Falco peregrinus, Lanner Falco biarmicus and Lesser Kestrel Falco naumanni. First, the accuracy of the NBD was tested in a reference area where the species abundance and occurrence were known through intensive field surveys. Next, an estimation of regional abundance derived from NBD was made for each species. These estimates were then compared to the existing regional data for the five raptors. The spatial distributions of the species were strongly aggregated, with $F$. peregrinus correctly showing the most widespread area of occupancy. The NBD gave a good approximation of the breeding abundance of the raptors, but tended to overestimate real data, particularly the regional data for falcons. Difficulties in species detection, insufficient sampling effort (F. biarmicus) or data collected over long time spans when population size increased (F. naumanni) may have reduced the NBD's resolution power. The ability of the method to predict local abundances over large areas from readily available presence-absence data, with relatively low fieldwork effort, could have considerable applications in conservation biology.
\end{abstract}

Keywords: distribution atlas, eagle, falcon, Lesser Kestrel, negative binomial distribution.

The atlas-distribution framework is a convenient approach for analysing species distribution, patterns of occurrence, abundance, rarity, and richness (Turner et al. 1988, Williams et al. 1996, Williams 1998, Wiens 2002). This framework uses standardized, near-equal area grid cells on maps at different spatial scales (Donald \& Fuller 1998). Distribution atlases, generally based on a Universal Transverse Mercator (UTM) projection, have become a concise way of summarizing species distribution at given geographical scales, from the continental (Hagemeijer \& Blair 1997) to the regional (e.g. Massa 1985, Lo Valvo et al. 1993).

The local abundance of a species is a key ecological parameter that becomes critical when making management and conservation decisions (Gaston \& Blackburn 2000, Guisan \& Thuiller 2005). For example, the fact-sheets of threatened species

*E-mail: mausar@unipa.it
(BirdLife International 2005) report population estimates for every country in which a species has been recorded. Abundance is valuable information for animal conservation, and is potentially available, but has been concealed, in distribution atlases, which, until a few years ago, neglected quantitative information on species abundance and other aspects of habitat suitability and preference. These atlases focused on presence-absence and often only reported qualitative estimates of species commonness or rarity. Both terms tended not to be theoretically defined because they are hard to relate accurately to atlas map scales, they vary with geographical scale, and they depend on several ecological factors (Rabinowitz 1981, Rabinowitz et al. 1986, Gaston 1994). Only recently have some national-scale atlases (Gibbons et al. 1993, Martì \& del Moral 2003) attempted to derive quantitative estimates of species abundances (Johnson \& Sargeant 2002). In addition, in many regions and for many taxonomic groups, logistical difficulties and costs hinder the implementation 
of extensive field monitoring programmes (e.g. Lawton et al. 1998). Thus, detection of precise local abundances for many species would by far exceed the resources available to researchers (Gaston et al. 2000). Accordingly, local abundances are often calculated based on surveys in a limited number of small sample areas and then extrapolated to large extents on coarse-scale maps (Gaston \& Blackburn 2000).

Investigations into how to predict fine-scale species abundances from coarse-scale presence-absence data have recently encouraged several studies (Nachmann 1981, Maurer 1990, Hanski \& Gillensberg 1997, Kunin 1998, He \& Gaston 2000a, 2000b). Generally, these authors have observed that spatial patterns of species occurrence on maps are largely dependent on the abundance of the species, its spatial distribution, the sampling scale and the sampling extent. Some researchers have attempted to develop mathematical models which encompass these variables. Recently, a model derived from the negative binomial distribution (henceforth NBD) was used (He \& Gaston $2000 \mathrm{a}, 2000 \mathrm{~b}$ ) to solve the problem of predicting abundance from occurrence maps.

I first tested the accuracy of the NBD in predicting the abundance of five threatened raptors (Table 1): Bonelli's Eagle Hieraaetus fasciatus, Golden Eagle Aquila chrysaetos, Peregrine Falco peregrinus, Lanner
Falco biarmicus and Lesser Kestrel Falco naumanni, in areas where species abundance was known from field counts, and the species occurrence was also mapped. Next, I enlarged the extent of sampling to the regional area (in the case of the Lesser Kestrel, to only $56 \%$ of the regional area), to produce the NBD estimation of regional abundance. This estimate was then compared to the existing regional data for the five raptors.

My principal aim was to explore the viability of predictive models, such as the NBD, as an alternative to direct counts for estimating the species abundance in a given area. Therefore, I was more interested in the comparison between intraspecific predictions of abundances (e.g. direct counts vs. NBD estimates) and less in the assessment of rarity or commonness of the five raptors in the study region.

\section{METHODS}

\section{The NBD method for extracting abundance estimates}

Kunin (1998) used the term 'scale-area curve' to describe the occurrence-abundance relationship. $\mathrm{He}$ and Gaston (2000a, 2000b) observed that the majority of animal and plant distributions were not random but aggregated, and introduced the term 'area-area

Table 1. Population characteristics of five raptor species, as summarized from the European IUCN Red List (IUCN 2006) and the current literature (Biber 1990, Del Hoyo et al. 1994, Hagemeijer \& Blair 1997, Baillie et al. 2004, BirdLife International 2005). The Sicilian population and regional trends are summarized from Di Vittorio and Sarà (2001), Di Vittorio (2006), lapichino and Massa (1989), Lo Valvo et al. (1993), Mascara (1984, 2002), Massa $(1985,1992)$ and Palumbo (1997).

\begin{tabular}{|c|c|c|c|c|c|c|c|c|}
\hline & $\begin{array}{l}\text { Life } \\
\text { history }\end{array}$ & $\begin{array}{l}\text { Population } \\
\text { unit }\end{array}$ & $\begin{array}{l}\text { Red List } \\
\text { Category }\end{array}$ & $\begin{array}{l}\text { Overall } \\
\text { trend }\end{array}$ & Major threats & $\begin{array}{c}\text { Italian } \\
\text { population }\end{array}$ & $\begin{array}{c}\text { Sicilian } \\
\text { population }\end{array}$ & $\begin{array}{l}\text { Regional } \\
\text { trend }\end{array}$ \\
\hline $\begin{array}{l}\text { Bonelli's } \\
\text { Eagle }\end{array}$ & Solitary & pair & $\begin{array}{l}\text { Endangered } \\
\text { SPEC3 }\end{array}$ & $\begin{array}{l}\text { Large } \\
\text { decline }\end{array}$ & $\begin{array}{l}\text { Power-line and wind } \\
\text { farm collisions, human } \\
\text { persecution, habitat change }\end{array}$ & $15-20$ & $16-17$ & $\begin{array}{l}\text { Stable-Low } \\
\text { decline }\end{array}$ \\
\hline $\begin{array}{l}\text { Golden } \\
\text { Eagle }\end{array}$ & Solitary & pair & $\begin{array}{l}\text { Least concern, } \\
\text { SPEC3 }\end{array}$ & Stable & $\begin{array}{l}\text { Human persecution, } \\
\text { reforestation in } \\
\text { mountainous habitat }\end{array}$ & $476-541$ & $17-18$ & $\begin{array}{l}\text { Stable-Low } \\
\text { decline }\end{array}$ \\
\hline Peregrine & Solitary & pair & $\begin{array}{l}\text { Least concern, } \\
\text { NO-SPEC }\end{array}$ & $\begin{array}{l}\text { Moderate } \\
\text { increase }\end{array}$ & $\begin{array}{l}\text { Now a secure species, } \\
\text { human persecution and } \\
\text { collisions affect local } \\
\text { populations/pairs }\end{array}$ & $787-991$ & 195-205 & $\begin{array}{l}\text { Moderate } \\
\text { increase }\end{array}$ \\
\hline Lanner & Solitary & pair & $\begin{array}{l}\text { Vulnerable, } \\
\text { SPEC3 }\end{array}$ & $\begin{array}{l}\text { Moderate } \\
\text { decline }\end{array}$ & $\begin{array}{l}\text { Human persecution, } \\
\text { egg and nestlings collection, } \\
\text { habitat loss and degradation }\end{array}$ & $100-140$ & $120-125$ & $\begin{array}{l}\text { Stable-Low } \\
\text { decline }\end{array}$ \\
\hline $\begin{array}{l}\text { Lesser } \\
\text { Kestrel }\end{array}$ & Colonial & colony & $\begin{array}{l}\text { Vulnerable, } \\
\text { SPEC1 }\end{array}$ & $\begin{array}{l}\text { Moderate } \\
\text { decline }\end{array}$ & $\begin{array}{l}\text { Habitat loss and } \\
\text { degradation, human } \\
\text { persecution }\end{array}$ & $3630-3840$ & $400-500$ & $\begin{array}{l}\text { Moderate } \\
\text { increase }\end{array}$ \\
\hline
\end{tabular}


curve' to explore the same relationship. They suggested using the NBD to model the spatial distribution of aggregated biological populations because from the NBD one can derive an area-area curve such that:

$A_{a}=A\left[1-(1+N a / A k)^{-k}\right]$

where $A_{a}$ is the area of occupancy, $A$ is the extent of the study area, $a$ is the sampling scale or Minimum Mapping Unit (MMU), $N$ is the abundance of the species, and $k$ is the aggregation parameter. By rearranging the former equation, an estimator of species' abundance was derived, which is:

$\tilde{N}=A k / a\left[\left(1-A_{a} / A\right)^{-1 / k}-1\right]$

The NBD model maps the occurrence of living organisms at two different scales of resolution (namely, the $a_{1}$ and $a_{2}$ MMUs) and assumes a constant $k$ among scales (He \& Gaston 2000b). However, in practice, $k$ seems to grow progressively larger at coarse-scales (Kunin et al. 2000). This produces a downward bias in abundance estimates at coarsescales. As a consequence, population estimates based on national-scale maps become unrealistically low (Kunin et al. 2000). Therefore to directly derive $\tilde{N}$ and $k, \mathrm{I}$ avoided the national-scale (generally the $50 \times 50 \mathrm{~km}$ UTM, or even larger) and I used smaller MMUs. In the case of the two eagles and larger falcons, they were: $a_{1}=20 \times 20 \mathrm{~km}$ UTM grid (coarse-scale), and $a_{2}=10 \times 10 \mathrm{~km}$ UTM grid (finescale). Then I used observed occurrences from field data at the fine-scale to derive those on the coarsescale. $A_{a_{1}}$ and $A_{a_{2}}$ were the areas of species occurrence at the $a_{1}, a_{2}$ MMUs, respectively. In the case of the Lesser Kestrel, those MMUs became: $a_{1}=10 \times 10 \mathrm{~km}$ UTM and $a_{2}=5 \times 5 \mathrm{~km}$ UTM. The species occurrences $A_{a_{1}}, A_{a_{2}}$ varied concurrently. It was then possible to solve a system of simultaneous equations to obtain the abundance $\tilde{N}$ and the aggregation parameter $k$ by means of the areas of occupancy mapped on two scales $a_{1}$ and $a_{2}$.

According to $\mathrm{He}$ and Gaston (2000a), positive values $(k \in 0+\infty)$, indicate that the probability of occurrence of a given species is derived from a negative binomial distribution. This allows for preliminarily checking that one species correctly fits the NBD. In addition, $k$ indicates the spatial pattern of species distribution; the smaller the value of $k$, the stronger is the aggregation of a given species. When $k$ moves from 0 to $\propto$, the spatial distribution consequently moves from aggregated to random.

\section{Occurrence and abundance recording of the eagles and larger falcons}

Real distribution maps do not usually have regular borders. However, for simplicity, statistical derivations dealt with in this study were based on a map with assumed regular borders, as the model so derived is equally applicable to irregular maps (He \& Reed 2006). The approach started with field records of species presence-absence, in the set of UTM grid cells best approximating to the irregular shape of Sicily (Fig. 1). The island's territory was incorporated into 72 UTM $20 \times 20 \mathrm{~km}$ cells $\left(a_{1}=\right.$ coarse-scale $)$, which corresponded to 288 UTM $10 \times 10 \mathrm{~km}$ cells $\left(a_{2}=\right.$ fine-scale). The total area $A$, which comprises sea in the coastal cells, is slightly more extended than the real island surface (an additional $3093 \mathrm{~km}^{2}$; Fig. 1).

In addition, I assumed that the modelling cell should fulfil the different ecological requirements of a species, as advised in Mackey and Lindenmayer (2001) and Guisan and Thuiller (2005). For better use in conservation planning, $\tilde{N}$ should be related, as carefully as possible, to the focal species' territorial unit detected in the field and mapped at the proper scale. As a consequence, the two MMUs, $a_{1}$ and $a_{2}$, were chosen as the best compromise of geographic scales representing the home-range sizes of the four eagles and larger falcons, as reported in general (Newton 1979, Cramp \& Simmons 1980) and regional (Di Vittorio 2006) literature. Field data of species presence were then plotted onto the cells at the $a_{1}$ and $a_{2}$ scales to produce the areas of occupancy $A_{a_{1}}, A_{a_{2}}$. These were calculated as the sum of the area of the corresponding UTM squares, so that one $20 \times 20 \mathrm{~km}$ UTM cell corresponds to $400 \mathrm{~km}^{2}$ and to four $10 \times 10 \mathrm{~km}$ UTM cells.

When working with atlas data, accurate proof of the true species absence in a cell is often difficult to obtain, and omission/commission errors may arise (Thuiller 2003). Undetected presences in some cells can add up to true absences in other cells, where habitat is unsuitable for the focal species, thereby introducing error in the occurrence estimate (Hirzel et al. 2002, 2006). For these reasons, I used four raptor species whose occurrences and abundances are fairly well known to ornithologists in Sicily, to apply the NBD method for predicting species abundance estimates. I assumed that the precise identification of all locations from which the considered species are absent is important, and that the ornithological knowledge about these species is good enough to minimize areas in which the species had gone unnoticed. 


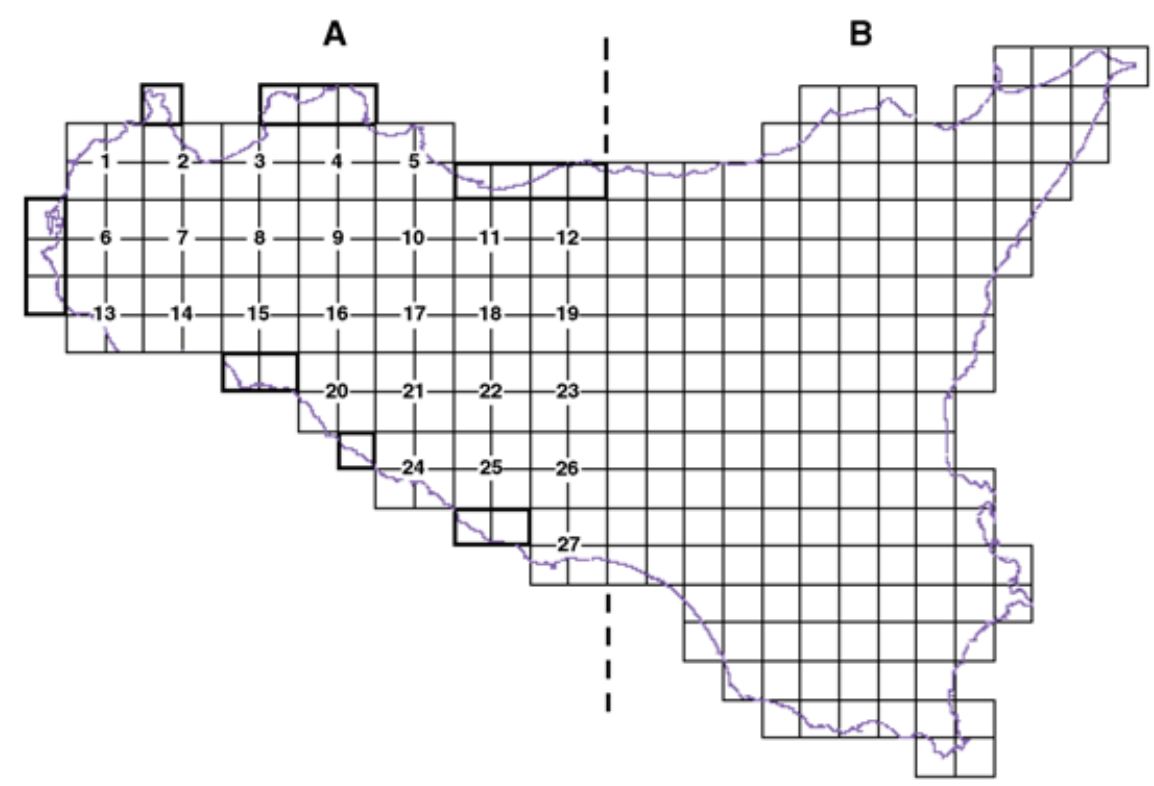

Figure 1. Map of Sicily incorporated into $7220 \times 20 \mathrm{~km} \mathrm{UTM}\left(a_{1}=\right.$ coarse-scale MMU) and $28810 \times 10 \mathrm{~km}$ UTM cells $\left(a_{2}=\right.$ fine-scale $\mathrm{MMU})$. The Western reference area (A), where both occurrences and abundances were known, corresponded to $3120 \times 20 \mathrm{~km} U \mathrm{UTM}$ $(12410 \times 10)$ cells. In area A, the numbers indicate $2720 \times 20$ cells and bold outlines the way in which further 4 coarse-scale coastal cells were obtained by joining groups of 4 spare $10 \times 10 \mathrm{~km}$ cells. The $4120 \times 20 \mathrm{~km}$ UTM cells of B were not indicated.

Most field data came from the ongoing 3rd Regional Atlas, which follows the 2nd (Lo Valvo et al. 1993) and 1st Regional Atlases (Massa 1985). The two eagles and the Peregrine have been more or less continuously monitored since 1979, the first year of the lst Regional Atlas, and several published estimates have been made available since then (see review in Di Vittorio \& Sarà 2001). Recently, the National Action Plan for the Lanner (Andreotti \& Leonardi 2007) and research on raptors in Sicily (Di Vittorio 2006) have increased available information. Nonetheless, as censuses of the whole population of every species were impossible, only sub-samples of sites were monitored in each season, and they were combined over several years to obtain regional estimates.

In this study, I excluded records of lone immature birds showing no evidence of territorial behaviour, and I expressed the presence of species in a cell in terms of territorial breeding pairs, irrespective of confirmed reproduction and breeding success. The known pairs were located on a map of Sicily at a scale of 1:250 000, with the UTM grid superimposed on it. For each species (Table 2), the sampled area (reference area A in Fig. 1) corresponded to the group of cells $\left(a_{1}=31 ; a_{2}=124\right)$ in which I was able to map the sites of territorial pairs, added to the group of cells
Table 2. The 'area-area curve' systems for the five raptor species. The total area $(A)$ covered by the $20 \times 20 / 10 \times 10$ MMUs is $28800 \mathrm{~km}^{2}$ for all the species, except for the Lesser Kestrel, where $A=16100 \mathrm{~km}^{2}$ on the $10 \times 10 / 5 \times 5$ MMUs. Figures are presented as occupied cells/sampled cells.

\begin{tabular}{lccc}
\hline & MMU & $\begin{array}{c}\text { Species } \\
\text { occupancy in } \\
\text { reference area }\end{array}$ & $\begin{array}{c}\text { Species } \\
\text { occupancy in } \\
\text { regional area }\end{array}$ \\
\hline Bonelli's Eagle & $20 \times 20$ & $12 / 31$ & $18 / 72$ \\
Golden Eagle & $10 \times 10$ & $16 / 124$ & $23 / 288$ \\
& $20 \times 20$ & $8 / 31$ & $16 / 72$ \\
Peregrine & $10 \times 10$ & $11 / 124$ & $19 / 288$ \\
Lanner & $20 \times 20$ & $26 / 31$ & $58 / 72$ \\
Lesser Kestrel & $10 \times 10$ & $60 / 124$ & $131 / 288$ \\
& $20 \times 20$ & $26 / 31$ & $51 / 72$ \\
& $10 \times 10$ & $62 / 124$ & $109 / 288$ \\
& $5 \times 5$ & $38 / 67$ & $61 / 161$ \\
& & $54 / 288$ & $103 / 644$ \\
\hline
\end{tabular}

where their absences were detected. These reference areas varied to some extent between species, due to their ecology and distribution and to the different survey areas for different species, but were coincident to western parts of Sicily (area A in Fig. 1). In those cells, I therefore identified the species' abundances 
by direct counts $\left(N_{\text {obs }}\right)$ which were used as controls and compared to the estimates $(\tilde{N})$ produced by the NBD method.

Subsequently, I repeated the procedure, extending the area of occupancy to the regional surface. In this case, to obtain the species occupancy, I simply added up the presence cells stored in the Atlas database in which I personally did not know the abundance (area B in Fig. 1). The second NBD estimate was then compared with the number of pairs reported in the regional literature for larger falcons. In the case of the two eagles, the availability of a long series of data on reproductive sites (1990-2006) allowed me to calculate the proportion $p$ of occupied sites every year $i$ and to compute the mean $p i$. The number of known sites was multiplied by the mean $p i$ to correct the regional population sizes. Estimates were rounded to integers $(0.5=1)$ to represent the number of pairs or colonies (see below).

\section{Occurrence and abundance recording of the Lesser Kestrel}

The Lesser Kestrel is of high conservation concern but has been monitored and studied less than other raptors in Sicily. To fill this gap, a survey was begun in 2000 under the auspices of the 3rd Regional Atlas (Di Vittorio \& Sarà 2001), but the data were intensively collected only from 2003 to 2007.

The rationale underlying the occurrence and abundance recording of the Lesser Kestrel differs slightly from that for eagles and larger falcons. According to the assumption followed for eagles and falcons (Mackey \& Lindenmayer 2001, Guisan \& Thuiller 2005), the scale resolution was adjusted according to Lesser Kestrel ranging behaviour. My choice was a coarse-scale $\left(a_{1}\right)$ equal to the $10 \times$ $10 \mathrm{~km}$ UTM grid and a fine-scale $\left(a_{2}\right)$ equal to the $5 \times 5 \mathrm{~km}$ UTM grid (Table 2). The latter scale of $25 \mathrm{~km}^{2}$ overlapped quite well with known home ranges in similar habitats (Tella et al. 1998, Franco et al. 2004).

A total of $16110 \times 10 \mathrm{~km}(6445 \times 5 \mathrm{~km}) \mathrm{UTM}$ cells were visited to survey Lesser Kestrel. Exploration started from two known areas of presence (Sicani in North West Sicily, and Gela Plain in the South East) and then expanded to the nearby UTM cells to get a representative sample of the regional area of occupancy (Fig. 2). At the end of the sampling, I was unable to explore all the 288 UTM cells and I lacked information on 127 cells. Among these there were 20 in which the species has been formerly detected

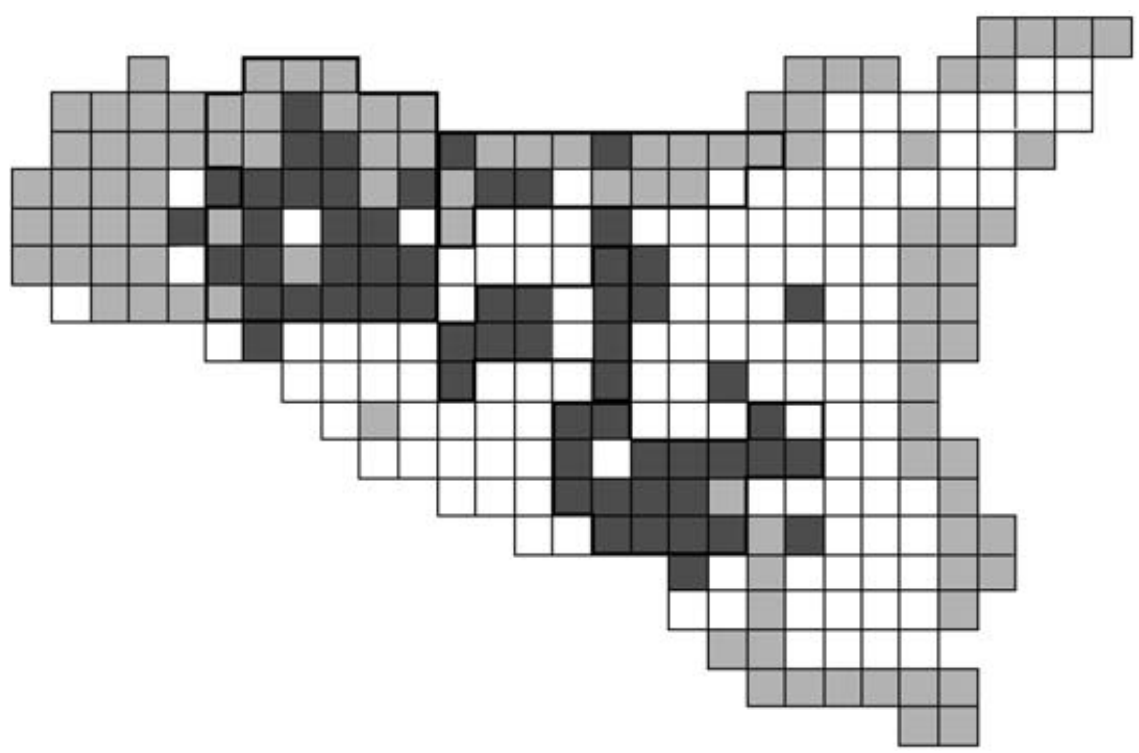

Figure 2. The $10 \times 10 \mathrm{~km}$ UTM Map of Sicily evidencing the four sub-sample areas where censuses of Lesser Kestrel were carried out (bold outlines). The composition of the 88 cells falling within the four sub-sample areas is in Appendix 1 . Total Lesser Kestrel presence in Sicily includes 38 quantitative and 13 qualitative cells inside the four sub-sample areas and 10 qualitative cells outside the four sub-sample areas (dark grey cells, $n=61$ ). Total Lesser Kestrel absence in Sicily inside and outside the four sub-sample areas is $n=100$ light grey cells. White cells indicate an unknown status of Lesser Kestrel $(n=127)$. 
(1979-1992). The total area $(A)$ was therefore less than that for the two eagles and falcons, and was equivalent to $16100 \mathrm{~km}^{2}$. Consequently, the regional predicted estimate $\tilde{N}$ referred to nearly $56 \%$ of the regional area. The total sample of 161 UTM squares was composed of cells in which the Lesser Kestrel was detected ( $n=40$, but presence confirmed in only 31 of them, and nine new absences), not detected in the two former atlases $(n=91)$, and from new presences $(n=30)$ outside the species range (as mapped in the 1st and 2nd Regional Atlases). The 100 absence cells were carefully inspected in the field to confirm the non-occurrence of the species. Generally, they represented unsuitable areas of agricultural intensification or coastal or mountain forested habitats.

The reference area of the Lesser Kestrel did not correspond to that of other species, but extended to central and eastern Sicily. The reference area of occupancy was formed by four sub-areas (Fig. 2, Appendix 1), in which the Lesser Kestrel proved absent in $2910 \times 10 \mathrm{~km}(1165 \times 5 \mathrm{~km})$ cells and in 38 other $10 \times 10 \mathrm{~km}(1525 \times 5 \mathrm{~km})$ cells, where quantitative data on the species' colonies were also recorded. Twenty-one other cells with insufficient data were not included in the reference area (Table 3). For the purposes of this study, I used field information from pair counts and bird ringing in

Table 3. Comparison between the statistics recorded by direct counts and the NBD estimation process in the reference and regional areas as defined in Table 2. $N_{\text {obs }}=$ number of eagles and large falcons pairs counted in the field; $\tilde{N} \pm s e=N B D$ predicted number of pairs \pm standard error; $k=$ aggregation parameter; $A_{a}=$ area of occupancy at the fine-scale; Total abundance $(N)^{a_{2}}$ is equivalent to the number of sites corrected by the mean proportion of occupied sites every year (eagles) and to counts from the regional literature (falcons).

\begin{tabular}{|c|c|c|c|c|}
\hline & $\begin{array}{c}\text { Bonelli's } \\
\text { Eagle }\end{array}$ & $\begin{array}{c}\text { Golden } \\
\text { Eagle }\end{array}$ & Peregrine & Lanner \\
\hline \multicolumn{5}{|l|}{ Reference area } \\
\hline$N_{\text {obs }}$ & 16 & 11 & 91 & 85 \\
\hline$\tilde{N} \pm$ se & $18 \pm 6$ & $13 \pm 6$ & $100 \pm 36$ & $109 \pm 42$ \\
\hline Difference $_{\text {(exp-obs) }}$ & 2 & 2 & 9 & 24 \\
\hline$k$ & 1.50 & 0.50 & 1.75 & 1.53 \\
\hline \multicolumn{5}{|l|}{ Regional area } \\
\hline Total Abundance $(N)$ & 17 & 16 & 195-205 & $120-125$ \\
\hline$\tilde{N} \pm \mathrm{se}$ & $25 \pm 7$ & $20 \pm 6$ & $216 \pm 52$ & $176 \pm 46$ \\
\hline Difference $_{\text {(exp-obs) }}$ & 8 & 4 & 21 & 76 \\
\hline$k$ & 0.73 & 1.13 & 1.47 & 0.99 \\
\hline$A_{a_{2}}\left(\mathrm{~km}^{2}\right)$ & 2300 & 1900 & 13100 & 10900 \\
\hline
\end{tabular}

territorial sites, counted at least once during the study period (mid April to early July of 2003-2007). The coordinates and characteristics of Lesser Kestrel sites were recorded in the field by a GPS device, identified on the same map used for the eagles and larger falcons, and then assigned to a UTM cell.

Lesser Kestrels live in colonies, contrary to the other raptors considered. Field data of occurrence thus provided information regarding the distribution of colonies rather than territorial pairs. This also meant that the abundance estimate I made with the NBD method referred to the number of colonies. To produce a final population estimate, it was necessary to multiply $\tilde{N}$ by a statistic averaging the number of breeding pairs in a sample of known colonies. To obtain unbiased known abundances in terms of colonies and pairs, to be further compared with the NBD estimates, I had to address the 100 territorial sites discovered within the reference area of occupancy. The process of site occupation in the Lesser Kestrel is rather complex (Serrano et al. 2001, 2003, Serrano \& Tella 2003). Especially in densely populated areas, the species has a composite pattern in which main colonies are surrounded by close satellite sites, or there are peripheral as well as alternative sites occupied or abandoned over succeeding years. This is precisely what is occurring in the SE area of Sicily, where there is an expanding population (Mascara \& Sarà 2006). For instance, in the 2006/7 seasons, the Lesser Kestrel occupied almost half of the rural houses considered as sub-optimal sites until 2005 in Mascara and Sarà (2006). To take this into consideration, all breeding sites falling within a radius of $1 \mathrm{~km}$ were grouped into a single colony, which reduced the sample of 100 territorial sites to 62 colonies (Appendix 2).

Colony surveys were undertaken following a rotating schedule (Mascara \& Sarà 2006) and nearly half of the colonies $(n=30)$, both large and small, were counted for 4-5 years (Appendix 2). Notwithstanding, there were 123 missing observations and the colonies themselves had different detection histories over the 5 -year period, during which time local extinction, colonization and recolonization of sites occurred. To take into consideration the variability in the detection histories of colonies, a simple proportionality rule between the number of sites checked every year and the number of pairs recorded was used. This allowed me to compute the $p i$ of active sites checked every year and then to estimate the number of unchecked active colonies. The estimated number of pairs for every year was obtained by adding the number of 
missed pairs (mean number of pairs in a checked colony times the estimated number of active colonies not checked) to the number of counted pairs. A bootstrapping procedure (1000 iterations) provided the means, standard errors and confidence intervals for these estimates. The estimated number of colonies in the reference area was compared to the NBD estimate by multiplying $\tilde{N}$ by the bootstrapped mean of pairs in active colonies, and thus I was able to express the expected NBD abundance in terms of Lesser Kestrel pairs in both the reference and regional area.

\section{RESULTS}

The 'area-area curve' systems for the five raptors are reported in Table 2 as the number of UTM cells of species occupancy in both the reference and regional areas.

\section{Occurrence and abundance of eagles and larger falcons}

The number of territorial pairs per species derived from direct counts in the UTM $10 \times 10 \mathrm{~km}$ cells are reported as $N_{\text {obs }}$ in Table 3 . The four species occurrences fitted the negative binomial distribution as shown by the positive values of $k$. This parameter also gives some information about the spatial distribution of the studied raptors, which is strongly aggregated (i.e. small $k$ ) for all species. The Golden Eagle had the most aggregated distribution in the reference area, possibly reflecting the clumping of pairs in distant mountain ranges of the reference area. The Peregrine had the least aggregation (i.e. the widest distribution) in the reference area, followed by the Lanner and Bonelli's Eagle. The NBD predicted a number of eagle and falcon pairs comparable to the data counted in the field; however, the NBD predictions tended to slightly overestimate the observed data and to have large standard errors, mostly with respect to the two falcon species.

I compared the NBD estimates for the entire region to the total abundances $(N)$ of eagles corrected for mean $p i \pm$ sd (Golden Eagle $=0.86 \pm 0.07$; Bonelli's Eagle $=0.75 \pm 0.08$ ), and to the estimates of falcons as recorded from the regional literature (Table 3). The regional NBD prediction showed again a certain degree of overestimation for eagles (Golden Eagle + four territories; Bonelli's Eagle + eight territories), but produced a much stronger upward bias in the abundance of the two falcons. This difference was more pronounced in the Lanner ( +76 territories) than in the Peregrine $(+21$ territories). The four species again fitted the negative binomial distribution, and $k$ values changed slightly with respect to those in the reference area (Table 3). Also, the species were strongly aggregated at the regional scale, the Peregrine being relatively more widespread all over the island and the other three species more aggregated in the suitable mid-southern (Lanner, Bonelli's Eagle) or mid-northern (Golden Eagle) habitats.

\section{Occurrence and abundance of the Lesser Kestrel}

The Lesser Kestrel was confirmed present in 31 of 40 $10 \times 10 \mathrm{~km}$ cells of past presence and confirmed absent in 91 cells of past absence. Hence, it disappeared from nearly $23 \%$ of the sampled former range. However, presence was recorded in 30 new cells, showing a net increase in the territorial coverage during the 2003/7 surveys with respect to the former atlases. Increased sampling effort can only be partially responsible for this result, as several new sites within those cells were previously known to be devoid of Lesser Kestrels.

The 100 territorial sites recorded in the field were grouped into 62 colonies, combining the small sites (satellites) present within $1 \mathrm{~km}$ of each main site (Appendix 2). The average number of satellites in the SE sub-sample area $(0.97 \pm 1.26 ; n=32)$, where the population was increasing, was larger than that of the other sub-sample areas $(0.23 \pm 0.63 ; n=30)$, a statistically significant difference $(Z=2.90 ; P=$ 0.004). Table 4 shows the results emerging from 5 years of counts in the Lesser Kestrel colonies and the bootstrapped statistics for the parameters of interest. The estimated total abundance of pairs has a large standard error and 90\% confidence intervals. This is in accordance with the high variability of pairs in Lesser Kestrel colonies (range 1-46 in the present dataset), as frequently reported (Donázar et al. 1993, Rodriguez Lopez 2001, Serrano et al. 2001, Serrano \& Tella 2003). The NBD method predicted $62 \pm 11$ colonies, strongly aggregated in the reference area $(k=4.33)$ and overestimated $(+7$ colonies; +63 pairs) the population (Table 4$)$. Accordingly, in $56 \%$ of the regional area the NBD estimated $138 \pm 29$ colonies, with $k=0.44$ in a finescale area of occupancy of $2575 \mathrm{~km}^{2}$. This figure corresponds to 1246 pairs. 
Table 4. Results of Lesser Kestrel census in the 62 colonies (Appendix 2) and derived bootstrapped statistics (mean \pm se and confidence intervals from 1000 replicates) used to compare the estimated population in the reference area to the NBD model estimates.

\begin{tabular}{lrrrrrr}
\hline & 2003 & 2004 & 2005 & 2006 & 2007 & Mean \pm se $(\mathrm{Cl} 90 \%)$ \\
\hline & & & & & & \\
$N$ pairs counted & 193 & 326 & 298 & 320 & 350 & $298 \pm 22(250-333)$ \\
$N$ checked colonies per year & 35 & 47 & 38 & 33 & 34 & \\
$N$ active colonies & 30 & 41 & 33 & 30 & 32 & \\
Mean $N$ pairs in active colonies & 6.43 & 7.95 & 9.03 & 10.67 & 10.94 & $9.04 \pm 0.72(7.76-10.24)$ \\
Proportion active colonies in the checked sites & 0.86 & 0.87 & 0.87 & 0.91 & 0.94 & \\
$N$ colonies not checked & 27 & 15 & 24 & 29 & 28 & \\
Estimated $N$ active colonies not checked & 23 & 13 & 21 & 26 & 26 & $55 \pm 1(54-56)$ \\
Estimated total $N$ active colonies & 53 & 54 & 54 & 56 & 58 & $55 \pm(412-582)$ \\
Estimated total $N$ pairs & 342 & 430 & 486 & 601 & 638 & $497 \pm 47(460$ \\
\hline
\end{tabular}

\section{DISCUSSION}

\section{The NBD method}

He and Gaston (2000b) suggested that the occupancyabundance relationship could be satisfactorily modelled at a fine-scale resolution; however, they advised using the same Minimum Mapping Unit for all the species to estimate rarity or commonness. Other studies (Holt et al. 2002, Warren et al. 2003, Tosh et al. 2004) also found that the NBD method consistently underestimated abundances at the coarser scale (i.e. the estimation becomes progressively poorer with the increase in the scale of the map). Kunin et al. (2000) indicated that the degree of auto-correlation of species occupancy across maps at different resolutions is the factor affecting the $k$-value variation between scales, thus causing abundance underestimation at coarser scales. Hui and McGeoch (2007) indicated that the NBD could essentially underestimate the real estimation due to a percolation effect. Nonetheless, this study shows that the NBD estimation for rare species appears to work particularly well. This is a strong point of the method, as abundance information for rare species is a major conservation concern, whereas it is apparent that a considerable degree of underestimation remains for very abundant species (He \& Reed 2006). Working with rare raptors, I found that the NBD corresponded reasonably well to the abundances of the two eagle species, Peregrine and Lesser Kestrel, but quite consistently overestimated Lanner abundance. Moreover, the difference between the observed abundances and the NBD predictions across species was mostly outside the 'well-known' reference area, where the method produced a relatively larger upward bias when I compared the predictions to data for the whole region. Once again, the Lanner had the worst outcome.

The degree of overestimation of observed abundances may occur for various reasons. First, overestimation is more common if a species actually has a more regular distribution than that detected in the field (He \& Reed 2006). Secondly, in this study, I have used a data collection scheme mostly based on surveys conducted over long time spans (e.g. for eagles and falcons: 2000-2006). As a consequence, data have been accumulated over several years, and field inspections (in several cases) have been aimed at confirming the presence of known pairs rather than exploring new areas. Arguably, such a data collection scheme may have underestimated the real regional populations by not considering a number of unnoticed pairs. It might not be a coincidence that the largest differences are for the Lanner, which is the most difficult species to detect and the least studied among the raptors considered, despite the efforts made in recent years (Di Vittorio 2006, Andreotti \& Leonardi 2007). Such discrepancies may not therefore be due to the NBD model being faulty, but to inaccurate estimates of regional eagle and falcon abundances.

There is another possible explanation for the large discrepancy found when applying the NBD method to the Lanner. As Andreotti and Leonardi (2007) recorded in an action plan sample area, every year, $40-45 \%$ of Lanner sites were deserted or nesting failed after an early occupation of sites. For this reason, they estimated that no more than $70-80$ pairs per year bred in Sicily. This is despite the fact that the 3rd Regional Atlas recorded presence in 90 UTM $10 \times 10 \mathrm{~km}$ cells and a mean of $1.38 \pm 0.56$ 
pairs per cell ( $n=59$ UTM squares), which would correspond to a regional population of 125 pairs. The explanations of such a high desertion rate include habitat modification and human disturbance (Andreotti \& Leonardi 2007), but it is likely that competition with the Peregrine is one of the most important reasons. On several cliffs, turnover between the two falcons has been recorded in Sicily (Di Vittorio et al. 2004). The trend for these changes was that the Peregrine occupied stable Lanner sites that were suddenly deserted. It is thus likely that fewer Lanner pairs could variably occupy and reoccupy a large number of sites between consecutive reproductive seasons. Pairs may therefore be moving among sites in the UTM cells sampled over several years. If this were the case, the exaggerated $\tilde{N}$ would have better predicted the Lanner's potential abundance in the absence of competition with the Peregrine.

Data collection over long time spans poses a further problem for the comparison of field counts and the $\mathrm{NBD}$, in the case of fluctuating population sizes, such as in the remarkably increasing Lesser Kestrel (or in any dramatically decreasing rare species). In such cases, accuracy may be improved by restricting surveys and analyses to some focal years. Notwithstanding, the results of the NBD application to the five raptors in Sicily are promising, and could indicate a method to assess the abundance of rare species in large areas with relatively low fieldwork effort. This could be particularly helpful in areas where presence-absence surveys using relatively simple methods may be the only reasonable and cost-effective option (Lawton et al. 1998, Petit et al. 2003, Tosh et al. 2004). Indeed, coupling well-standardized surveys to NBD estimations could become an effective procedure for estimating the magnitude of species abundance from atlas datasets. This may be worthwhile in the case of national as well as European action plans, or schemes aimed at detecting abundances of threatened species (e.g. species data fact-sheets; BirdLife International 2005). A well-budgeted survey made in a single season and in a large (at least $50 \%$ ) reference area could turn out to be a practical and reliable method to estimate abundance of focal species (or groups of species) of conservation interest in any area-area system.

Different species, taxonomic groups or guilds could have different optimal scale resolutions at which their abundances are best rendered. It is also likely that conspicuous, large-size species would need sampling scales at relatively lower resolution than those required for secretive or small-size species (see
He \& Reed 2006). Therefore, one must take into consideration species-specific ecological traits when applying the NBD. The biological need of an optimal scale dictated by species ecology or life history (Mackey \& Lindenmayer 2001, Guisan \& Thuiller $2005)$ assumes variance of scales across species. This is contrary to the scale-invariance assumption and related mathematical properties of the model ( $\mathrm{He} \&$ Gaston 2000b, Hartley \& Kunin 2003). Hartley and Kunin (2003) have already focused on this aspect and suggested overcoming the problem using multi-scale approaches and rarity indices that combine information from multiple scales.

The estimate of $\tilde{N}$ may express different concepts with respect to solitary or colonial species. To predict reasonably the abundances of a colonial species by the NBD, I had to incorporate the species' territorial unit detected in the field (i.e. the 'colony'). The simple recording of 100 Lesser Kestrel territorial sites would have produced a strong downward bias in the $\tilde{N}$ from the NBD. The grouping of several close sites in a single colony was in accordance with the known influence of climate on colony occupancy rate (Rodriguez \& Bustamante 2003) and the complex features affecting natal dispersal of birds, as well as the colonization and desertion of Lesser Kestrel colonies (Negro et al. 1997, Serrano et al. 2001, 2003, Serrano \& Tella 2003). This was verified in Sicily (Mascara \& Sarà 2006 and 10 unpublished recaptures of ringed birds in the SE population), and produced a much better convergence between the observed and predicted estimates in the reference area. Further application of the NBD method to colonial species, such as seabirds or wetland birds living in large and continuous habitats, should address the structure of those animal groups. This may require some previous knowledge of the population system of the focal species and the introduction of corrections to the NBD estimation process.

\section{Study species}

My contribution confirmed the known regional rarity of the two eagles and falcons, as predicted by the total number of potentially occupied sites $\tilde{N}$, and the area of occupancy $A_{a}$ (7-9\% of Sicily for the eagles and $42-51 \%$ for the falcons). Also, after a better exploration of mid-eastern Sicily, it is likely that the current ecological conditions of Sicily cannot support more than 20-22 potential sites for both eagles and 150-200 for both falcons. Specific projects are needed to protect these eagles and the Lanner, for 
instance, by enlarging their area of occupancy $\left(A_{a}\right)$ to avoid the risk of extinction typical of small populations (Frankham et al. 2002).

According to the NBD, there could be at least 138 colonies and 1246 Lesser Kestrel pairs in $56 \%$ of the regional area. This simulation, and results in Mascara and Sarà (2006), confirm that Sicily is one of the few major viable Lesser Kestrel natural areas - together with Monegros in Spain (De La Fuente 2004) and Apulia in Italy (Palumbo 1997, 2001). The current state of this population focuses on the Sicilian government's responsibilities in the conservation planning of the Lesser Kestrel. We urge that local specific actions be implemented under the Natura 2000 network to prevent heavy habitat loss following the policy of intensification of dry and traditional agricultural systems (Donald et al. 2001, Brotons et al. 2004).

This study was funded by an ex-60\%-2003 grant: 'Gestione della Biodiversità (Vertebrati terrestri) e degli habitat d'interesse comunitario (Sic e ZPS)'. I would like to thank R. Mascara, L. Zanca and N. Diliberto for their extensive contribution to the fieldwork on Lesser Kestrel. M. Di Vittorio, A. Falci, S. Falcone, S. Grenci, B. Massa, R. Ientile and other ornithologists provided much data regarding the species' presence. E. Giudice provided data and facilities while studying in the Gela area. G. Lavagetto wrote the FORTRAN program to run the NBD method. Also, I acknowledge the constructive remarks of J. Seoane and of an anonymous referee on an early draft of this paper.

\section{REFERENCES}

Andreotti, A. \& Leonardi, G. 2007. Piano d'azione nazionale per il Lanario (Falco biarmicus feldeggi). Quaderni Conservazione Natura. Ministero Ambiente 24: 1-109.

Baillie, J.E.M., Hilton-Taylor, C. \& Stuart, S.N. 2004. IUCN Red List of Threatened Species. A Global Species Assessment. Cambridge: IUCN

Biber, J.P. 1990. Action Plan for the Conservation of Western Lesser Kestrel Falco naumanni Populations. Cambridge: ICBP.

BirdLife International. 2005. Species fact sheets. http:// www.birlife.org.

Brotons, L., Mañosa, S. \& Estrada, J. 2004. Modelling the effect of irrigation schemes on the distribution of steppe birds in Mediterranean farmland. Biodivers. Conserv. 13: 10391058.

Cramp, S. \& Simmons, K.E.L. (eds) 1980. The Birds of the Western Palearctic, Vol. 2. Oxford: Oxford University Press.

De la Fuente, M.A. 2004. Desarollo y ejecucion del Plan de Conservacion del habitat del Cernicalo primilla (Falco naumanni). Actas del VI Congreso Nacional sobre el Cernicalo primilla: 53-61. Gobierno de Aragon: Departamiento de Medio Ambiente.
Del Hoyo, J., Elliot, A. \& Sargatal, J. 1994. Handbook of the Birds of the World, Vol. 2. Barcelona: Lynx Edicions.

Di Vittorio, M. 2006. Biologia e conservazione di cinque specie di Uccelli Rapaci in Sicilia. Doctoral thesis, Palermo: Università di Palermo.

Di Vittorio, M. \& Sarà, M. 2001. Status of Raptors in Sicily: Report year 2000. - Abstract Book 4th Eurasian Congress on Raptors: 56. Seville: Estacion Biologica Doñana.

Di Vittorio, M., Grenci, S., Falcone, S. \& Sarà, M. 2004. Comparative ecology of Lanner (Falco biarmicus) and Peregrine (Falco peregrinus). In Sanz, J. \& Brotons, L. (eds) International Symposium on Ecology and Conservation of Steppe-Land Birds: 189. Lerida: Centre Tecnològic Forestal de Catalunya.

Donald, P.F. \& Fuller, R. 1998. Ornithological atlas data: a review of uses and limitations. Bird Study 45: 129-145.

Donald, P.F., Green, R.E. \& Heath, M.F. 2001. Agricultural intensification and the collapse of Europe's farmland bird populations. Proc. R. Soc. Lond. B 268: 25-29.

Donázar, J.A., Negro, J.J. \& Hiraldo, F. 1993. Foraging habitat selection, land-use changes and population decline in the Lesser Kestrel Falco naumanni. J. Appl. Ecol. 30: 515522.

Franco, A.M.A., Catry, I., Sutherland, W.J. \& Palmeirim, J.M. 2004. Do different habitat preference survey methods produce the same conservation recommendations for lesser kestrels? Anim. Conserv. 7: 291-300.

Frankham, R., Ballou, J.D. \& Briscoe, D.A. 2002. Introduction to Conservation Genetics. Cambridge: Cambridge University Press.

Gaston, K.J. 1994. Rarity. London: Chapman and Hall.

Gaston, K.J. \& Blackburn, T.M. 2000. Pattern and Process in Macroecology. Oxford: Blackwell Science.

Gaston, K.J., Blackburn, T.M., Greenwood, J.J.D., Gregory, R.D., Quinn, R.M. \& Lawton, J.H. 2000. Abundance-occupancy relationships. J. Appl. Ecol. 37: 39-59.

Gibbons, D.W., Reid, J.B. \& Chapman, R.A. 1993. The New Atlas of Breeding Birds in Britain and Ireland: 1988-1991. London: $T$ \& $A D$ Poyser.

Guisan, A. \& Thuiller, W. 2005. Predicting species distribution: offering more than simple habitat models. Ecol. Lett. 8 : $1-17$.

Hagemeijer, W.A.J. \& Blair, M.J. 1997. The EBCC Atlas of European Breeding Birds. Their Distribution and Abundance. London: T \& AD Poyser.

Hanski, I. \& Gyllenberg, M. 1997. Uniting two general patterns in the distribution of species. Science 275: 397-400.

Hartley, S. \& Kunin, W.E. 2003. Scale dependency of rarity, extinction risk, and conservation priority. Conserv. Biol. 17: 1559-1570.

He, F. \& Gaston, K.J. 2000a. Estimating species abundance from occurrence. Am. Nat. 156: 553-559.

He, F. \& Gaston, K.J. 2000b. Occupancy-abundance relationships and sampling scales. Ecography 23: 503-511.

He, F. \& Reed, W. 2006. Downscaling abundance from the distribution of species: occupancy theory and applications. In Wu, J., Jones, B., Li, H. \& Loucks, O. (eds) Scaling and Uncertainty Analysis in Ecology: Methods and Applications: 89-108. New York: Springer.

Hirzel, A.H., Hausser, J., Chessel, D. \& Perrin, N. 2002. Ecological-niche factor analysis: how to compute habitat-suitability maps without absence data? Ecology 83: 2027-2036. 
Hirzel, A.H., Le Lay, G., Helfer, V., Randin, C. \& Guisan, A. 2006. Evaluating the ability of habitat suitability models to predict species presences. Ecol. Model. 199: 142-152.

Holt, A.R., Gaston, K.J. \& He, F. 2002. Occupancy-abundance relationships and spatial distribution: a review. Basic Appl. Ecol. 3: 1-13.

Hui, C. \& McGeoch, M.A. 2007. Capturing the 'droopy-tail' in the occupancy-abundance relationship. Ecoscience 14: 103108.

lapichino, C. \& Massa, B. 1989. The Birds of Sicily. British Ornithologists' Union. Check list no. 11. Dorchester: Henry Ling Ltd.

IUCN. 2006. 2006 IUCN Red List of Threatened Species. www.iucnredlist.org.

Johnson, D.H. \& Sargeant, G.A. 2002. Towards better atlases: improving presence-absence information. In Scott, M.S., Heglund, P.J., Morrison, M.L., Haufler, J.B., Raphael, M.G., Wall, W.A. \& Samson, F.B. (eds) Predicting Species Occurrences: Issues on the Accuracy and Scale: 391-398. Covelo: Island Press.

Kunin, W.E. 1998. Extrapolating species abundance across spatial scales. Science 281: 1513-1515.

Kunin, W.E., Hartley, S. \& Lennon, J.J. 2000. Scaling down: on the challenge of estimating abundance from occurrence patterns. Am. Nat. 156: 560-566.

Lawton, J.H., Bignel, D.E., Bolton, B., Bloemers, G.F., Eggleton, P., Hammond, P.M., Hodda, M., Holt, R.D., Larsen, T.B., Mawdsley, N.A., Stork, N.E., Srivastava, D.S. \& Watt, A.D. 1998. Biodiversity inventories, indicator taxa and effects of habitat modification in tropical forest. Nature 391: 72-76.

Lo Valvo, M., Massa, B. \& Sarà, M. 1993. Uccelli e Paesaggio in Sicilia alle Soglie del Terzo Millennio. Naturalista Sicil. Palermo: Luxograph Editrice.

Mackey, B.G. \& Lindenmayer, D.B. 2001. Towards a hierarchical framework for modelling the spatial distribution of animals. J. Biogeog. 28: 1147-1166.

Martì, R. \& del Moral, J.C. 2003. Atlas de la Aves Reproductoras de España. Madrid: Direccìn General de Conservacìon de la Naturaleza. Societad Española de Ornitologia.

Mascara, R. 1984. Censimento e note sulla biologia riprodutiva di alcuni falconiformi della Sicilia Centro-Meridionale (Aves Falconiformes). Naturalista Siciliano 8: 3-12.

Mascara, R. 2002. Censimento della popolazione nidificante di grillaio, Falco naumanni, nell'area della Piana di Gela (Sicilia). Riv. It. Ornitol. 71: 213-216.

Mascara, R. \& Sarà, M. 2006. Densità e biologia riproduttiva del grillaio Falco naumanni nella piana di Gela (Sicilia). Avocetta 30: $51-59$.

Massa, B. 1985. Atlas Faunae Siciliae - Aves. Naturalista Siciliano 9: 1-274.

Massa, B. 1992. Falco grillaio (Falco naumanni). In Brichetti, P., De Franceschi, P. \& Baccetti, N. (eds) Fauna d'Italia - Aves I. Gaviidae-Phasianidae: 488-493. Bologna: Edagricole.

Maurer, B.A. 1990. The relationship between distribution and abundance in a patchy environment. Oikos 58: 181-189.

Nachmann, G. 1981. A mathematical model of the functional relationship between density and spatial distribution of a population. J. Anim. Ecol. 50: 453-460.

Negro, J.J., Hiraldo, F. \& Donázar, J.A. 1997. Causes of natal dispersal in the lesser kestrel: inbreeding avoidance or resource competition? J. Anim. Ecol. 66: 640-648.
Newton, I. 1979. Population Ecology of Raptors. Berkhamsted: $T \& A D$ Poyser.

Palumbo, G. 1997. // Grillaio. Matera: Altrimedia SAS.

Palumbo, G. 2001. El Cernìcalo primilla (Falco naumanni) en Italia: distribucion y consistencia de las colonias. Descripcìon de lo métodos de censo de la poblacìon. In Garcés Toledano, J.F. \& Corroto Matesanz, M. (eds) Actas del IV Congreso Nacional Sobre el Cernicalo Primilla: 294-304. Madrid: Consejerìa de Medio Ambiente.

Petit, S., Chamberlain, D., Haysom, K., Pywell, R., Vickery, J., Warman, L., Allen, D. \& Firbank, L. 2003. Knowledgebased models for predicting species occurrence in arable conditions. Ecography 26: 626-640.

Rabinowitz, D.S. 1981. Seven forms of rarity. In Singe, H. (ed.) The Biological Aspects of Rare Plant Conservation: 205217. Chichester: Wiley.

Rabinowitz, D.S., Cairns, S. \& Dillon, T. 1986. Seven forms of rarity and their frequency in the flora of the British Isles. In Soulè, M.E. (ed.) Conservation Biology: The Science of Scarcity and Diversity: 182-204. Sunderland: Sinauer.

Rodriguez Lopez, C. 2001. Factores ambientales y otros factores que determinan la dinamica poblacional del Cernìcalo primilla (Falco naumanni). In Garcés Toledano, J.F. \& Corroto Matesanz, M. (eds) Actas del IV Congreso Nacional Sobre el Cernícalo Primilla: 23-30. Madrid: Consejerìa de Medio Ambiente.

Rodriguez, C. \& Bustamante, J. 2003. The effect of weather on Lesser Kestrel breeding success: can climate change explain historical population declines? J. Anim. Ecol. 72: 793-810.

Serrano, D. \& Tella, J.L. 2003. Dispersal within a spatially structured population of Lesser Kestrels: the role of spatial isolation and conspecific attraction. J. Anim. Ecol. 72: 400-410.

Serrano, D., Tella, J.L. \& Donázar, J.A. 2001. Factors affecting breeding dispersal in the facultatively colonial Lesser Kestrel: individual experience vs. conspecific cues. J. Anim. Ecol. 70: 568-578.

Serrano, D., Tella, J.L., Donázar, J.A. \& Pomarol, M. 2003. Social and individual features affecting natal dispersal in the colonial Lesser Kestrel. Ecology 84: 3044-3054.

Tella, J.L., Forero, M.G., Hiraldo, F. \& Donázar, J.A. 1998. Conflicts between Lesser Kestrel conservation and European agricultural policies as identified by habitat use analyses. Conserv. Biol. 12: 593-604.

Thuiller, W. 2003. BIOMOD - optimising prediction of species distributions and projecting potential future shift under global change. Global Change Biol. 9: 1353-1362.

Tosh, C.A., Reyers, B. \& van Jaarsveld, A.S. 2004. Estimating the abundances of large herbivores in the Kruger National Park using presence-absence data. Anim. Conserv. 7: 5562.

Turner, J.R.G., Lennon, J.J. \& Lawrenson, J.A. 1988. British bird species distribution and the energy theory. Nature 335: 539-541.

Warren, M., Mcgeoch, M.A. \& Chown, S.L. 2003. Predicting abundance from occupancy: a test for an aggregated insect assemblage. J. Anim. Ecol. 72: 468-477.

Wiens, J.A. 2002. Predicting species occurrences: progress, problems and prospects. In Scott, M.S., Heglund, P.J., Morrison, M.L., Haufler, J.B., Raphael, M.G., Wall, W.A. \& Samson, F.B. (eds) Predicting Species Occurrences: Issues on the Accuracy and Scale: 739-749. Covelo: Island Press. 
Williams, P.H. 1998. Key sites for conservation: area-selection methods for biodiversity. In Mace, G.M., Balmford, A. \& Ginsberg, J.R. (eds) Conservation in a Changing World: 221-249. Cambridge: Cambridge University Press.

Williams, P.H., Gibbons, D.W., Margules, C.R., Rebelo, A.G., Humphries, C.J. \& Pressey, R.L. 1996. A comparison of richness hotspots, rarity hotspots and complementary areas for conserving diversity using British birds. Conserv. Biol. 10: 15-74.

Received 17 April 2007;

revision accepted 5 June 2008.

Appendix 1 Details (number of $10 \times 10$ UTM cells) of the four sub-sample areas where intensive field research on Lesser Kestrel was carried out (Fig. 2). The reference area ( $n=67$, in Table 2) corresponds to the 38 cells in which presence was recorded and estimated by point counts in 100 territorial sites, plus the 29 absence cells. A further 21 cells ( 13 of qualitative presence in which the number of colonies was not counted; and 8 not explored) were not included in the NBD model for the reference area.

\begin{tabular}{|c|c|c|c|c|c|}
\hline & Quantitative presence & Absence & Qualitative presence & Not explored & Total \\
\hline North-west & 15 & 16 & 5 & 2 & 38 \\
\hline North & 3 & 12 & 1 & 2 & 18 \\
\hline Central & 7 & 0 & 3 & 2 & 12 \\
\hline \multirow[t]{2}{*}{ South-east } & 13 & 1 & 4 & 2 & 20 \\
\hline & 38 & 29 & 13 & 8 & 88 \\
\hline
\end{tabular}


Appendix 2 The detection history and number of pairs of 62 Lesser Kestrel colonies recorded in the four sub-sample areas (Fig. 2 , Appendix 1) and counted in 5 years (2003-07). $\mathrm{nr}=$ not recorded.

\begin{tabular}{|c|c|c|c|c|c|c|}
\hline & Sub-sample area & 2003 & 2004 & 2005 & 2006 & 2007 \\
\hline Colony 1 & North-west & $\mathrm{nr}$ & 5 & 0 & 0 & $\mathrm{nr}$ \\
\hline Colony 2 & North west & 17 & 16 & 15 & 8 & $\mathrm{nr}$ \\
\hline Colony 3 & North-west & 10 & 5 & 4 & 3 & 1 \\
\hline Colony 4 & North-west & 20 & 0 & 0 & 7 & $\mathrm{nr}$ \\
\hline Colony 5 & North-west & $\mathrm{nr}$ & 2 & 4 & 2 & 0 \\
\hline Colony 6 & North-west & $\mathrm{nr}$ & 2 & $\mathrm{nr}$ & $\mathrm{nr}$ & $\mathrm{nr}$ \\
\hline Colony 7 & North-west & 0 & 14 & 14 & $\mathrm{nr}$ & 11 \\
\hline Colony 8 & North-west & 3 & 11 & 10 & $\mathrm{nr}$ & 3 \\
\hline Colony 9 & North-west & $\mathrm{nr}$ & $\mathrm{nr}$ & $\mathrm{nr}$ & 5 & 9 \\
\hline Colony 10 & North-west & $\mathrm{nr}$ & 2 & 3 & $\mathrm{nr}$ & $\mathrm{nr}$ \\
\hline Colony 11 & North-west & $\mathrm{nr}$ & 9 & 11 & $\mathrm{nr}$ & 8 \\
\hline Colony 12 & North-west & 0 & 0 & 2 & $\mathrm{nr}$ & 4 \\
\hline Colony 13 & North-west & $\mathrm{nr}$ & 10 & 14 & $\mathrm{nr}$ & 17 \\
\hline Colony 14 & North-west & 4 & 6 & 3 & $\mathrm{nr}$ & 12 \\
\hline Colony 15 & North-west & $\mathrm{nr}$ & 9 & 8 & $\mathrm{nr}$ & 4 \\
\hline Colony 16 & North & 5 & 5 & 2 & 11 & 5 \\
\hline Colony 17 & North & 0 & 3 & 0 & 0 & $\mathrm{nr}$ \\
\hline Colony 18 & North & 3 & 0 & 0 & 0 & $\mathrm{nr}$ \\
\hline Colony 19 & Central & $\mathrm{nr}$ & 4 & $\mathrm{nr}$ & $\mathrm{nr}$ & $\mathrm{nr}$ \\
\hline Colony 20 & Central & $\mathrm{nr}$ & 14 & $\mathrm{nr}$ & $\mathrm{nr}$ & 11 \\
\hline Colony 21 & Central & $\mathrm{nr}$ & 4 & $\mathrm{nr}$ & $\mathrm{nr}$ & $\mathrm{nr}$ \\
\hline Colony 22 & Central & $\mathrm{nr}$ & 4 & $\mathrm{nr}$ & $\mathrm{nr}$ & $\mathrm{nr}$ \\
\hline Colony 23 & Central & $\mathrm{nr}$ & 4 & $\mathrm{nr}$ & $\mathrm{nr}$ & $\mathrm{nr}$ \\
\hline Colony 24 & Central & 5 & 11 & 4 & 6 & 3 \\
\hline Colony 25 & Central & 4 & $\mathrm{nr}$ & $\mathrm{nr}$ & $\mathrm{nr}$ & $\mathrm{nr}$ \\
\hline Colony 26 & Central & $\mathrm{nr}$ & 9 & 5 & $\mathrm{nr}$ & $\mathrm{nr}$ \\
\hline Colony 27 & Central & $\mathrm{nr}$ & 9 & 5 & 4 & $\mathrm{nr}$ \\
\hline Colony 28 & Central & $\mathrm{nr}$ & 3 & 3 & $\mathrm{nr}$ & $\mathrm{nr}$ \\
\hline Colony 29 & Central & $\mathrm{nr}$ & $\mathrm{nr}$ & $\mathrm{nr}$ & 4 & $\mathrm{nr}$ \\
\hline Colony 30 & Central & $\mathrm{nr}$ & $\mathrm{nr}$ & $\mathrm{nr}$ & 5 & $\mathrm{nr}$ \\
\hline Colony 31 & South-east & 10 & $\mathrm{nr}$ & $\mathrm{nr}$ & $\mathrm{nr}$ & $\mathrm{nr}$ \\
\hline Colony 32 & South-east & $\mathrm{nr}$ & 7 & $\mathrm{nr}$ & $\mathrm{nr}$ & $\mathrm{nr}$ \\
\hline Colony 33 & South-east & $\mathrm{nr}$ & $\mathrm{nr}$ & $\mathrm{nr}$ & 3 & 5 \\
\hline Colony 34 & South-east & $\mathrm{nr}$ & $\mathrm{nr}$ & $\mathrm{nr}$ & 4 & 0 \\
\hline Colony 35 & South-east & $\mathrm{nr}$ & 3 & $\mathrm{nr}$ & $\mathrm{nr}$ & $\mathrm{nr}$ \\
\hline Colony 36 & South-east & $\mathrm{nr}$ & 2 & $\mathrm{nr}$ & $\mathrm{nr}$ & $\mathrm{nr}$ \\
\hline Colony 37 & South-east & 3 & 5 & 13 & 21 & 17 \\
\hline Colony 38 & South-east & 3 & 8 & 14 & 19 & 26 \\
\hline Colony 39 & South-east & $\mathrm{nr}$ & 9 & $\mathrm{nr}$ & $\mathrm{nr}$ & 4 \\
\hline Colony 40 & South-east & 4 & 4 & $\mathrm{nr}$ & $\mathrm{nr}$ & 4 \\
\hline Colony 41 & South-east & $\mathrm{nr}$ & 3 & 13 & 6 & 7 \\
\hline Colony 42 & South-east & 9 & $\mathrm{nr}$ & $\mathrm{nr}$ & $\mathrm{nr}$ & $\mathrm{nr}$ \\
\hline Colony 43 & South-east & 5 & 6 & 6 & 9 & 11 \\
\hline Colony 44 & South-east & 9 & 20 & 18 & 17 & 15 \\
\hline Colony 45 & South-east & 2 & 0 & 5 & 9 & 5 \\
\hline Colony 46 & South-east & 14 & 16 & 19 & 26 & 17 \\
\hline Colony 47 & South-east & 1 & 0 & 0 & 4 & 8 \\
\hline Colony 48 & South-east & $\mathrm{nr}$ & 10 & 11 & 19 & 21 \\
\hline Colony 49 & South-east & 6 & 10 & 16 & 29 & 22 \\
\hline Colony 50 & South-east & $\mathrm{nr}$ & 3 & 3 & 4 & $\mathrm{nr}$ \\
\hline Colony 51 & South-east & 7 & $\mathrm{nr}$ & $\mathrm{nr}$ & $\mathrm{nr}$ & $\mathrm{nr}$ \\
\hline Colony 52 & South-east & 19 & 33 & 24 & 24 & 20 \\
\hline Colony 53 & South-east & 0 & 0 & 3 & 2 & 7 \\
\hline Colony 54 & South-east & 0 & 2 & 5 & 6 & 6 \\
\hline Colony 55 & South-east & 5 & $\mathrm{nr}$ & 6 & 11 & 12 \\
\hline Colony 56 & South-east & 2 & $\mathrm{nr}$ & 5 & 7 & 5 \\
\hline Colony 57 & South-east & 5 & $\mathrm{nr}$ & 2 & 5 & 4 \\
\hline Colony 58 & South-east & 7 & 18 & 28 & 40 & 46 \\
\hline Colony 59 & South-east & 6 & 6 & $\mathrm{nr}$ & $\mathrm{nr}$ & $\mathrm{nr}$ \\
\hline Colony 60 & South-east & 3 & $\mathrm{nr}$ & $\mathrm{nr}$ & $\mathrm{nr}$ & $\mathrm{nr}$ \\
\hline Colony 61 & South-east & 1 & $\mathrm{nr}$ & $\mathrm{nr}$ & $\mathrm{nr}$ & $\mathrm{nr}$ \\
\hline Colony 62 & South-east & 1 & $\mathrm{nr}$ & $\mathrm{nr}$ & $\mathrm{nr}$ & $\mathrm{nr}$ \\
\hline
\end{tabular}

